\title{
Evidences of organic acids exudation in aluminium stress responses of two Madeiran wheat (Triticum aestivum L.) landraces
}

\author{
Marta Rodrigues (1) José Filipe T. Ganança • \\ Emanuel M. da Silva • Teresa M. M. dos Santos • \\ Jan J. Slaski · Janusz Zimny $\cdot$ Miguel Â. A. Pinheiro de Carvalho
}

Received: 24 October 2018/Accepted: 4 February 2019/Published online: 14 February 2019

(C) Springer Nature B.V. 2019

\begin{abstract}
Two wheat (Triticum aestivum L.) Madeiran landraces were subjected to $100 \mu \mathrm{M}$ and $200 \mu \mathrm{M}$ of aluminium (Al) in hydroponic culture, assessing the organic acid exudation role in plant's responses to this metal. Samples of initial landrace populations $\left(\mathrm{F}_{0}\right), \mathrm{F}_{3}$ and haplodiploid lines $(\mathrm{DH})$ were evaluated using standard tests: eriochrome cyanine $\mathrm{R}$ staining, root elongation and callose accumulation in roots. Root exudates were obtained to determine if the accumulation of malic and citric acids in hydroponic medium was a response to $\mathrm{Al}$ exposure. Additionally, the presence of ALMT1 gene was determined using five microsatellite markers. Standard tests confirmed that ISOP 76 was Al tolerant and ISOP 239, $\mathrm{Al}$ susceptible. ISOP 76, in the presence of $100 \mu \mathrm{M} \mathrm{Al}$, exuded substantially more malic acid
\end{abstract}

M. Rodrigues $(\bowtie) \cdot$ J. F. T. Ganança ·

E. M. da Silva · T. M. M. dos Santos •

J. J. Slaski · M. Â.A. Pinheiro de Carvalho

ISOPlexis Genebank, University of Madeira, 9000-390

Funchal, Portugal

e-mail: marta.rodrigues@staff.uma.pt

J. J. Slaski · M. Â.A. Pinheiro de Carvalho

ICAAM, University of Évora, Évora, Portugal

\section{J. J. Slaski}

InnoTech Alberta, Ecosystems and Plant Sciences,

Vegreville, AB, Canada

\section{J. Zimny}

Institute of Plant Breeding and Acclimatization,

Radzikow, Poland
(12.87 to $43.33 \mathrm{mg} / \mathrm{L}$ ), than ISOP 239 (3.65 to $7.72 \mathrm{mg} / \mathrm{L}$ ). The levels of both organic acid exudation were substantially lower in ISOP 239 than in the ISOP 76. In the presence of $200 \mu \mathrm{M} \mathrm{Al}$, ISOP $76 \mathrm{~F}_{0}$ shows a higher root elongation ratio (better tolerates $\mathrm{Al}$ ), but the $\mathrm{DH}$ line was the one that exuded higher content of malic acid. Different gene alleles and promoters were detected in both landraces. Molecular differences could explain the observed dissimilarity in organic acid exudation response to $\mathrm{Al}$ stress.

Keywords Haplodiploid lines ·

Aluminium tolerance .

Eriochrome cyanine R staining .

Organic acids exudation - ALMT1 gene .

Microsatellite markers

\section{Introduction}

Wheat is the third most harvested cereal worldwide (Shewry 2009). In many parts of the world, wheat is cultivated on acidic soils that affect $40 \%$ of arable land globally (Yang et al. 2012). Soil acidity is one of the main constrains of high wheat yield, with low $\mathrm{pH}$ (below 4.5) making aluminium cationic form to become bioavailable to plant roots, affecting their growth and capacity to uptake water and nutrients (Ma et al. 2001). Crop productivity due to aluminium (Al) toxicity can be reduced by 60\% (Haug 1984). Therefore, screening of wheat genetic resources 
under such edaphic conditions and understanding mechanisms of aluminium tolerance are vital. Different physiological tests have been developed to assess plants' Al tolerance, including measurements of root elongation, staining with eriochrome cyanide $\mathrm{R}$ and quantification of callose accumulation in root tips (Pinheiro de Carvalho et al. 2003, dos Santos et al. 2005).

The Archipelago of Madeira is an outmost Portuguese Region in the Atlantic Ocean, with volcanic origin where geochemical processes have contributed to the increase of soil acidity (Madeira et al. 1994, Pinheiro de Carvalho et al. 2003, Ganança et al. 2007). Wheat was the first crop introduced to Madeira by early settlers who arrived to the islands almost 600 years ago (Vieira 1988). Since then, the crop has developed a wide range of diversity (dos Santos et al. 2012) including landraces adapted to soil acidity and Al bioavailability (Pinheiro de Carvalho et al. 2003, Ganança et al. 2007).

Aniol (1990) hypothesized that wheat can develop several strategies to cope with $\mathrm{Al}$ stress. Importance of exclusion mechanisms in response to elevated $\mathrm{Al}$ in growing medium was emphasised by Rout et al. (2001). Generally, roots exude organic acids such as malic and citric acids, that are able to precipitate aluminium cations in soil (Ma et al. 2001; Ryan et al. 2009). Ryan et al. (2011) postulated the involvement of the protein TaALMT1 (Triticum aestivum Aluminium-Activated Malate Transporter) in exudation of malic acid by forming an ion channel across the plasma membrane to the apoplast. The ALMT1 gene is required to express this transporter protein and its structure includes a promoter, six exons and five introns (Raman et al. 2008). Several molecular markers are used to detect the ALMT1 gene. The most common ones are SSR (Single Sequence Repeats) markers that encode small sequences located in the gene's introns and the CAPS (Cleavage Amplification Polymorphism Sequence) marker that is in an exon (Raman et al. 2008). Enzymatic digestion of CAPS amplified product allows to distinguish between two alleles, ALMT1-1 and ALMT1-2 (Jones et al. 2009). Finally, there are two other markers for the gene promoter, LPF (Long Promoter Fragment) and SPF (Short Promoter Fragment), which indicates what type of promoter is present in plant tissues. Promoter type I allows the lowest expression of the ALMT1 gene, while promoters type VI, featuring triplicated sequence repeats, show the highest gene expression (Sasaki et al. 2006).

The overall goal of this study was to elucidate the early detection role of organic acids exudation in different $\mathrm{Al}$ tolerance level of two Madeira wheat landraces, ISOP 76 and ISOP 239. This was achieved by the comparison of landraces responses to $\mathrm{Al}$ exposure in nutrient solution and by correlation between $\mathrm{Al}$ tolerance, exudation of organic acids by the roots, and ALTM1 gene presence and polymorphism.

\section{Materials and methods}

\section{Plant material}

Two landraces of wheat, obtained from the ISOPlexis Gene Bank at the University of Madeira, Serra represented by ISOP 76 belonging to Triticum aestivum L. var. erythrospermum (Körn.) Mansf. and Rapado branco, ISOP 239, Triticum aestivum L. var. milturum (Alef.) Mansf. (dos Santos et al. 2009), were used. The initial populations $\left(F_{0}\right), F_{3}$ selected generations, and the haplodiploid lines (DH), obtained from $F_{1}$ plants of each landrace were compared. $\mathrm{F}_{3}$ generations were selected for $\mathrm{Al}$ tolerance (ISOP 76) or susceptibility (ISOP 239) from the previously screened plants using the eriochrome cyanine R staining (Pinheiro de Carvalho et al. 2003). DH lines were developed at the Institute of Plant Breeding and Acclimatization, Radzikow, Poland, using the $F_{1}$ generation plants. This process started with the tillers harvest at the stage of the uninucleated microspore to two-nucleated pollen grain. After cold pre-treatment, the spikes were surface sterilised and washed in sterile water. Anthers were removed from the spike and put on solidified medium. They were subsequently cultured in Petri dishes in the dark at $26{ }^{\circ} \mathrm{C}$. Developing embryos and callus were transferred to regeneration media. Small green plantlets were transferred to the Erlenmeyer flasks containing MS medium (Murashige and Skoog 1962) for rooting. Plantlets were then planted into pots and grown in a greenhouse until maturity.

The Brazilian variety Maringá was also used as a standard for aluminium tolerance (Basu et al. 1994). Additionally, Chinese Spring, a moderately tolerant 
variety, was used as a standard in the detection of SSRs molecular markers (Basu et al. 1994; Ma et al. 2006).

Seed germination, screening and exudates collection

Random samples of $\mathrm{F}_{0}, \mathrm{~F}_{3}$ and $\mathrm{DH}$ lines of each landrace were analysed. Eighty seeds without any symptoms of fungi contaminations were selected from each group. The seeds were surface sterilized for $30 \mathrm{~min}$. with $0.1 \%$ Benlate (fungicide) solution and then transferred for $20 \mathrm{~min}$ to $10 \%$ sodium hypochlorite and for $3 \mathrm{~min}$ to $70 \%$ ethanol. Subsequently, the seeds were germinated for 3 days in Petri dishes containing solid MS medium to check for fungi contaminations. Thirty six non-contaminated seedlings were transferred to sterile hermetic vessels (3 per vessel) containing $30 \mathrm{~mL}$ of nutrient solution, $\mathrm{pH}$ 4.3. This solution contained $2.0 \mathrm{M}$ calcium nitrate, $0.6 \mathrm{M}$ magnesium nitrate, $0.6 \mathrm{M}$ ammonia nitrate, $0.2 \mathrm{M}$ dipotassium phosphate, $0.2 \mathrm{M}$ potassium sulphate and $0.8 \mathrm{M}$ potassium nitrate (Pinheiro de Carvalho et al. 2003). The seedlings were maintained in the gently stirred vessels for $48 \mathrm{~h}$ under a photoperiod of $9 \mathrm{~h}$ of light and $15 \mathrm{~h}$ of dark. Previously, Ganança et al. (2007) showed that $48 \mathrm{~h}$ incubation allows seedlings to overcome possible stressfully conditions, resulting from its transference from solid to liquid growth medium. Afterwards, the plantlets were divided into three subsamples and transferred to experimental solutions, $\mathrm{pH} 4.0$, containing $1.0 \mathrm{mM}$ calcium nitrate, $0.3 \mathrm{mM}$ magnesium nitrate and $3.3 \mathrm{mM}$ ammonia nitrate, added with $0 \mathrm{mM}$ (control), $0.1 \mathrm{mM}$ (aluminium I) or $0.2 \mathrm{mM}$ (aluminium II) of aluminium chloride (Pinheiro de Carvalho et al. 2003), and grew for 9 days. During experimental period, the $\mathrm{pH}$ of growth solution has controlled and kept between 4.0 and 4.5 by addition of $1.0 \mathrm{~N} \mathrm{HCl}$ or $\mathrm{NaOH}$. The length of experiment was determined by the vessels volume. During this period seedlings were able to grow and exude enough organic acids to be quantified by the enzymatic kits. At the end of the experiment, both plants and the corresponding nutrient solutions were collected for further analysis.
Screening tests

Length of the main root was manually measured, using a calibre digital pachymeter $150 \mathrm{~mm}$, at the end of the experiment. The seedlings were tested for $\mathrm{Al}$ tolerance or sensitivity, using the eriochrome cyanine $\mathrm{R}$ staining method and the measurement of callose accumulation in root tips. Roots of 30 plants of each experimental variant of $\mathrm{F}_{0}, \mathrm{~F}_{3}$ and $\mathrm{DH}$ lines were stained with the dye as described by Pinheiro de Carvalho et al. (2003) and the number of plants with irreversibly damaged root apex was computed.

Root apices harvested from a different set of 30 plants of each experimental variant of $\mathrm{F}_{0}, \mathrm{~F}_{3}$ and $\mathrm{DH}$ lines were used to quantify callose accumulation as described by dos Santos et al. (2005).

Exudates analysis and organic acids quantification

At the end of the assay, growth solutions containing exudates were recovered and screened for microbial contaminations through the incubation of a drop of solution onto universal growth medium. Contaminated growth solutions were discarded. To noncontaminated growth solution, was added $0.05 \%$ of sodium azide $(\mathrm{v} / \mathrm{w})$ and the solutions were stored at $20{ }^{\circ} \mathrm{C}$. Subsequently, growth solutions were lyophilized and the final pellet was suspended in $2 \mathrm{~mL}$ of ultrapure water. Lyophilisation at $-50{ }^{\circ} \mathrm{C}$ allows to concentrate the organic acid avoiding its destruction by heating.

The enzymatic kits L-Malic Acid, Megazyme (Megazyme International Ireland 2012) and Citric Acid, Megazyme (Megazyme International Ireland 2014) were used to quantify malic and citric acids exuded by roots into growth solution.

DNA extraction and molecular markers detection

Nine days old leaves of seedlings were collected and deeply frozen, with liquid nitrogen and stored at $20{ }^{\circ} \mathrm{C}$ for DNA extraction. DNA extraction from the tissues of landraces and standards was made according to Chao and Somers (2015). Molecular markers detection was performed using the iProof HighFidelity Master Mix kit (Bio-Rad). The markers amplifications were performed in a thermocycler PxE 0.2 , Thermohybaid using the programmes described in Table 1. 
Table 1 Molecular markers and PCR programmes used in the detection of ALMT1 gene during the screening of sequences of $\mathrm{F}_{0}$ and $\mathrm{F}_{3}$ generations of wheat landraces and the DH lines

\begin{tabular}{|c|c|c|}
\hline Markers & Primer's sequences & PCR programmes \\
\hline APS & $\begin{array}{l}\text { F: 5'-GGA ATG GAA TTC AAC TGC TTT GGC G-3' } \\
\text { R: 5'-TCC TCA GTG GCC TTC GAA TTA AGG-3' }\end{array}$ & $\begin{array}{l}\mathbf{1} \times\left(98{ }^{\circ} \mathrm{C} 1^{\prime}\right), \mathbf{4 0} \times\left(98{ }^{\circ} \mathrm{C} 10^{\prime \prime}-67.5^{\circ} \mathrm{C} 30^{\prime \prime}-72{ }^{\circ} \mathrm{C} 30^{\prime \prime}\right), \mathbf{1} \times\left(72{ }^{\circ} \mathrm{C}\right. \\
\left.10^{\prime}\right)\end{array}$ \\
\hline SSR3a & $\begin{array}{l}\text { F: 5'-CTC GTC ACA AAA GCC ACT CA-3' } \\
\text { R: 5'-GAC GCA ATC AAG GGG AAT AA-3' }\end{array}$ & $\begin{array}{l}\mathbf{1} \times\left(98{ }^{\circ} \mathrm{C} 1^{\prime}\right), \mathbf{4 0} \times\left(98{ }^{\circ} \mathrm{C} 10^{\prime \prime}-56.5^{\circ} \mathrm{C} 30^{\prime \prime}-72{ }^{\circ} \mathrm{C} 30^{\prime \prime}\right), \mathbf{1} \times\left(72{ }^{\circ} \mathrm{C}\right. \\
\left.10^{\prime}\right)\end{array}$ \\
\hline SSR3b & $\begin{array}{l}\text { F: 5'-ATG CCA TTT CTT CTG TAC TGA CA-3' } \\
\text { R: 5'-AAA GAG TCC TCA GTG GCC TTC GAA-3' }\end{array}$ & $\begin{array}{l}\mathbf{1} \times\left(98{ }^{\circ} \mathrm{C} 1^{\prime}\right), \mathbf{3 5} \times\left(98{ }^{\circ} \mathrm{C} 10^{\prime \prime}-61.5^{\circ} \mathrm{C} 30^{\prime \prime}-72{ }^{\circ} \mathrm{C} 30^{\prime \prime}\right), \mathbf{1} \times\left(72{ }^{\circ} \mathrm{C}\right. \\
\left.10^{\prime}\right)\end{array}$ \\
\hline SPF & $\begin{array}{l}\text { F: 5'-GCT CCT ACC ACT ATG GTT GCG-3' } \\
\text { R: 5'-CCA GGC CGA CTT TGA GCG AG-3' }\end{array}$ & $\begin{array}{l}\mathbf{1} \times\left(98{ }^{\circ} \mathrm{C} 1^{\prime}\right), \mathbf{4 0} \times\left(98{ }^{\circ} \mathrm{C} 10^{\prime \prime}-64{ }^{\circ} \mathrm{C} 30^{\prime \prime}-72{ }^{\circ} \mathrm{C} 30^{\prime \prime}\right), \mathbf{1} \times\left(72{ }^{\circ} \mathrm{C}\right. \\
\left.10^{\prime}\right)\end{array}$ \\
\hline LPF & $\begin{array}{l}\text { F: 5'-CCT GGT TTT CTT GAT GGG GGC ACA-3' } \\
\text { R: 5'-TGC CCA CCA TCT CGC CGT CGC TCT CTC } \\
\text { T-3' }\end{array}$ & $\begin{array}{l}\mathbf{1} \times\left(98{ }^{\circ} \mathrm{C} 1^{\prime}\right), \mathbf{3 5} \times\left(98{ }^{\circ} \mathrm{C} 10^{\prime \prime}-70.5^{\circ} \mathrm{C} 30^{\prime \prime}-72{ }^{\circ} \mathrm{C} 30^{\prime \prime}\right), \mathbf{1} \times\left(72{ }^{\circ} \mathrm{C}\right. \\
\left.10^{\prime}\right)\end{array}$ \\
\hline
\end{tabular}

Amplification products were separated and detected on $1.4 \%(\mathrm{w} / \mathrm{v})$ agarose gels. Additional enzyme restriction of PCR products to identify the CAPS alleles was performed, using enzyme XmnI (New England BioLabs) and separated on a $2.2 \%(\mathrm{w} / \mathrm{v})$ agarose gel.

Data treatment

Experiments were performed twice, using three replicates per experimental variant. Averages, standard deviations and graphics were made using Microsoft Excel, while statistical tests including One-Way and Two-Way ANOVA and Pearson correlations were determined using the software Statistical Package for the Social Sciences (SPSS ver. 22).

\section{Results}

Eriochrome cyanine R test

Root staining with eriochrome cyanide $\mathrm{R}$ allows to differentiate tolerant from susceptible plants by coloration of the root apex (Pinheiro de Carvalho et al. 2003). All individuals of ISOP 76 appeared to be tolerant (Fig. 1). The $\mathrm{F}_{0}$ generation of ISOP 239 had more than $55 \%$ of susceptible individuals and this susceptibility increased with the selection (Fig. 1). In the Maringá population, $75 \%$ of plants were tolerant to aluminium, proving to be a good tolerance standard (Fig. 1).

\section{Root length}

The elongation ratio derived by calculating the ratio of root length between experimental and control variants indexes to their $\mathrm{Al}$ tolerance. This ratio (data not showed) confirms that Maringá have smaller root growth, but exhibited the best root performance, regarding $\mathrm{Al}$ increasement in the growing medium (Fig. 2). The root measurements revealed that the $F_{0}$, $\mathrm{F}_{3}$ and DH generations of ISOP 76, in all experimental variants, exhibited higher root length than the standard Maringá (Fig. 2). The Al bioavailability affects ISOP 76 root elongation in an increasing rate, between 26 and $36 \%$ in the presence of $200 \mu \mathrm{M} \mathrm{Al}$. At the same time, $F_{0}$ of ISOP 239 displayed a higher root length in the absence of $\mathrm{Al}$ and at $100 \mu \mathrm{M}$ of $\mathrm{Al}$ when compared to Maringá, but no significant differences were observed in the presence of $200 \mu \mathrm{M}$ of Al. These differences become less evident in $\mathrm{F}_{3}$ and the DH lines of ISOP 239 (Fig. 2). So, ISOP 239 suffers the highest impact of Al bioavailability in root elongation, between $63\left(\mathrm{~F}_{0}\right)$ and $47 \%(\mathrm{DH})$ in the presence of $200 \mu \mathrm{M} \mathrm{Al}$. Both landraces shown better root elongation in the $\mathrm{F}_{0}$ and in presence $100 \mu \mathrm{M} \mathrm{Al}$. However, results of root elongation and root elongation ratio are higher in the ISOP 76 than in ISOP 239, and even comparable with Maringá root elongation ratio. 
Fig. 1 Evaluation of tolerance of the wheat lines from Madeira Island to $200 \mu \mathrm{M} \mathrm{AlCl}{ }_{3}$ in nutrient solution using the eriochrome cyanine $\mathrm{R}$ staining method. Three-dayold seedlings were exposed to aluminium for 6 days and subsequently placed in the dye. Root apex of the tolerant plants remained white, while susceptible plants exhibited orange root apex

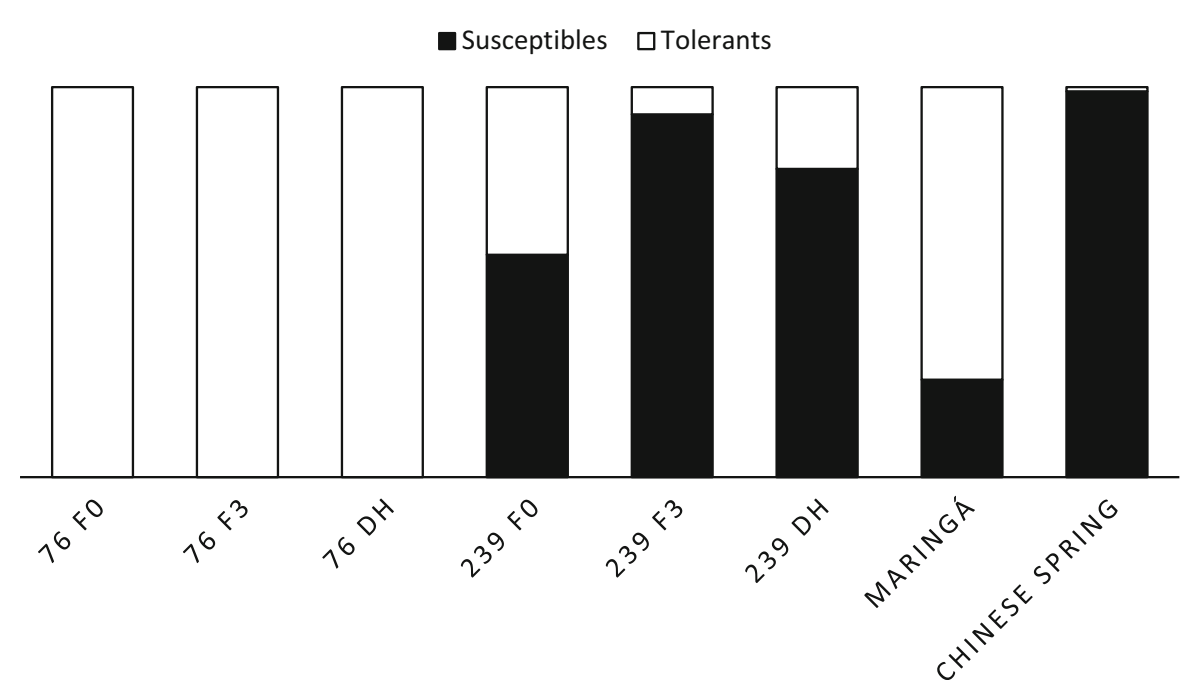

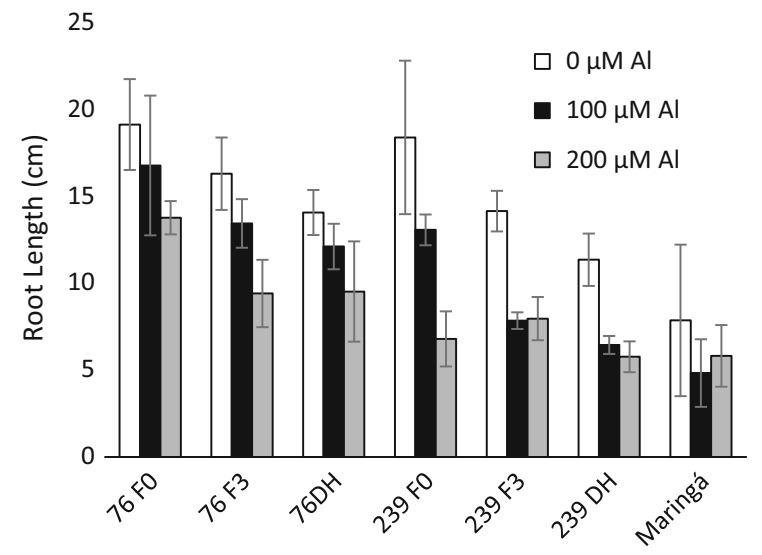

Fig. 2 Root length of wheat lines, from Madeira Island, exposed for 9 days to 100 or $200 \mu \mathrm{M}$ aluminium in nutrient solution. Data represents the mean $\pm \mathrm{SD}$

\section{Callose}

Callose accumulation is a precise quantitative test displaying tissue's response to the presence of aluminium (Fig. 3). The quantity of callose and the ratio between control and experimental conditions (data not showed) indicated that the increase in $\mathrm{Al}$ concentration was positively correlated with the callose accumulation in every landrace's generation or line tested (Table 3). Accumulation of callose by the ISOP 76 lines closely resemble the pattern observed in the standard Maringá (Fig. 3), although overpasses its callose amount in 1.0 and 1.6 folds in the presence of 100 and $200 \mu \mathrm{M}$ of $\mathrm{Al}$, respectively. The comparison between $\mathrm{F}_{0}$ of ISOP 239 and

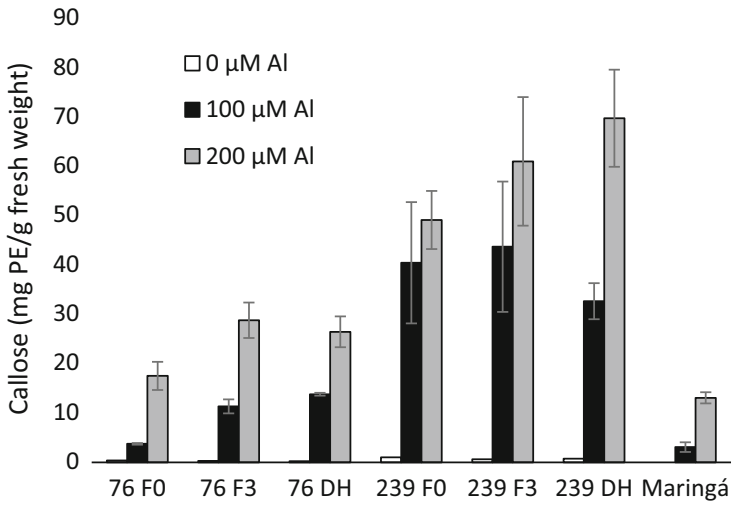

Fig. 3 Callose content in roots tips of wheat lines, from Madeira Island, exposed for $24 \mathrm{~h}$ to 100 or $200 \mu \mathrm{M}$ aluminium in nutrient solution. Data represents the mean $\pm \mathrm{SD}$ of triplicate extractions

Maringá shows that callose accumulation has higher 19.5 and 4.1 folds in the presence of 100 and $200 \mu \mathrm{M}$ of $\mathrm{Al}$, respectively. Callose accumulation in the roots of $\mathrm{F}_{3}$ and $\mathrm{DH}$ line of both landraces increases, although it is almost threefolds lower in the roots of the ISOP 76.

Quantification of organic acids in exudates

In the absence of Al, ISOP 76 roots exuded lower quantity of malate when compared to roots grown in the presence of $\mathrm{Al}$ (Fig. 4a). The $\mathrm{F}_{0}$ generation of ISOP 76 exuded four times more malic acid than Maringá, in the presence of $200 \mu \mathrm{M} \mathrm{Al}$. In the presence of $100 \mu \mathrm{M} \mathrm{Al}$, the highest malate exudation 
Fig. 4 Malic acid (a) and Citric acid (b) exuded by wheat lines, from Madeira Island, exposed for 9 days to 100 or $200 \mu \mathrm{M}$ aluminum in nutrient solution. Data represents the mean $\pm \mathrm{SD}$

\section{(A)}

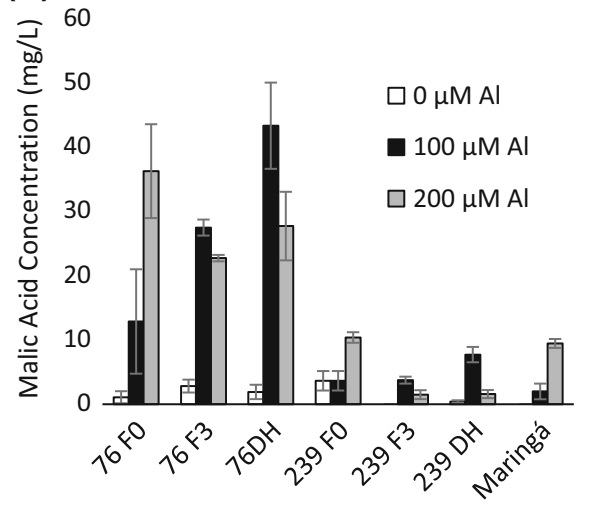

(B)

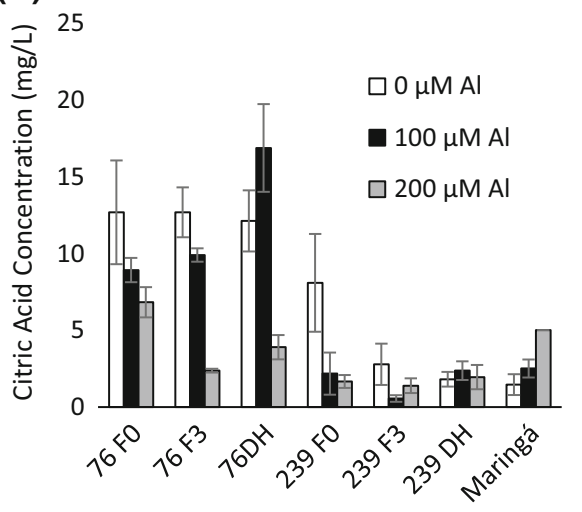

was reported in the DH line followed by $\mathrm{F}_{3}$ and $\mathrm{F}_{0}$ while a slightly different trend $\left(\mathrm{F}_{0}<\mathrm{DH}<\mathrm{F}_{3}\right)$ was observed in the presence of $200 \mu \mathrm{M} \mathrm{Al}$ (Fig. 4a). At the same time, malic acid exudation appeared to be unspecific or non-significant in ISOP 239 and absent in Maringá. The exudation of citric acid, in the absence of $\mathrm{Al}$, was the highest in the ISOP 76, intermediate in the ISOP 239 and absent in Maringá (Fig. 4b). The citric acid exudation decreases, with the presence of $\mathrm{Al}$, in all landraces lines, at exception of $76 \mathrm{DH}$ line and Maringá in the presence of $200 \mu \mathrm{M}$ $\mathrm{Al}$,

A comprehensive summary of the tolerance tests and organic acid exudation for $\mathrm{F}_{0}$ generations is provided (Table 2). ISOP 76, in the presence of $100 \mu \mathrm{M} \mathrm{Al}$, had the highest number of tolerant individuals and malic acid exudation, whereas Maringá shows the biggest root length. In the same experimental variant, ISOP 239 had the highest callose deposition. The two-way ANOVA (Table 3) shows significant influence $(p>0.01)$, of both generations and experimental variants (presence of $\mathrm{Al}$ ), in the variation of root length or callose accumulation (tolerance or sensitivity) or in the malic or citric exudation (mitigation strategy). The values of $\mathrm{Z}$ coefficient shows that presence of $\mathrm{Al}$ in growth medium was a key factor in the observed results, namely the root elongation, callose elongation and citric acid exudation. However, in the variation of malic acid exudation, the generation factor had more weight. The one way ANOVA (data not shown) demonstrated that Al presence had a significant influence in the variation of malic acid exudation in the $\mathrm{F}_{0}, \mathrm{~F}_{3}$ and $\mathrm{DH}$ of the ISOP 76. In the case of ISOP 239 , this influence was observed only in the $F_{3}$ and DH lines. Statistical bivariate analysis (Tables 4, 5), using Pearson correlation coefficient shows that, malic acid exudation appears negatively correlated $(p>0.05)$ with root elongation and positively correlated with callose accumulation $(p>0.05$ and $p>$ 0.01 ) in $\mathrm{F}_{0}$ e $\mathrm{F}_{3}$ of ISOP76. At the same time, in the ISOP 239 no significant correlations of malic acid with the other parameters was observed, and root elongation is the unique parameter that had

Table 2 Summary of screening tests results assessing performance of Maringá (benchmark) and $\mathrm{F}_{0}$ generations of the Madeiran landraces in the presence of $100 \mu \mathrm{M} \mathrm{AlCl}{ }_{3}$

\begin{tabular}{llll}
\hline Tests & Maringá & ISOP 76 & ISOP 239 \\
\hline Eriochrome cyanide R & \pm & + & - \\
Root length & + & \pm & - \\
Callose deposition & - & \pm & + \\
Malate exudation & - & + & - \\
Citrate exudation & + & + & - \\
\hline
\end{tabular}

+ High pronunciation; \pm medium pronunciation; - low pronunciation 
Table 3 Statistical analyses of the screening tests using Two-way ANOVA

\begin{tabular}{|c|c|c|c|c|c|c|c|c|}
\hline \multirow[t]{2}{*}{ Source } & \multicolumn{2}{|c|}{ Root length } & \multicolumn{2}{|l|}{ Callose } & \multicolumn{2}{|c|}{ Malic acid } & \multicolumn{2}{|l|}{ Citric acid } \\
\hline & $\mathrm{Z}$ & Sig. & $\mathrm{Z}$ & Sig. & $\mathrm{Z}$ & Sig. & $\mathrm{Z}$ & Sig. \\
\hline Generation & $54.642 *$ & 0.000 & $79.585^{*}$ & 0.000 & $19.550^{*}$ & 0.000 & $8.121^{*}$ & 0.001 \\
\hline Experimental variant & $116.870^{*}$ & 0.000 & $470.610^{*}$ & 0.000 & $9.559^{*}$ & 0.000 & $11.559 *$ & 0.000 \\
\hline Generation $\times$ experimental variant & $4.942 *$ & 0.000 & $27.725^{*}$ & 0.000 & $3.685^{*}$ & 0.001 & $2.626 * *$ & 0.011 \\
\hline
\end{tabular}

*The correlation is significant at the 0.01 level

**The correlation is significant at the 0.05 level

Table 4 Pearson correlations (PC) between screening tests for ISOP 76: root length (RL), malic acid exudation (MA), citric acid exudation (CA) and callose accumulation (C)

\begin{tabular}{|c|c|c|c|c|c|c|c|c|c|c|c|c|}
\hline & \multicolumn{4}{|l|}{$\mathrm{F}_{0}$} & \multicolumn{4}{|l|}{$\mathrm{F}_{3}$} & \multicolumn{4}{|l|}{$\mathrm{DH}$} \\
\hline & RL & CA & & $\mathrm{C}$ & RL & MA & $\mathrm{CA}$ & $\mathrm{C}$ & RL & MA & $\mathrm{CA}$ & $\mathrm{C}$ \\
\hline \multicolumn{13}{|l|}{ RL } \\
\hline $\mathrm{PC}$ & 1.000 & $-0.722 *$ & $0.691 *$ & $0.677 *$ & 1.000 & $-0.747 *$ & $0.874 * *$ & $-0.895 * *$ & 1.000 & -0.157 & 0.534 & $-0.694 *$ \\
\hline Sig. & - & 0.028 & 0.039 & 0.022 & - & 0.021 & 0.002 & 0.000 & - & 0.687 & 0.139 & 0.012 \\
\hline \multicolumn{13}{|l|}{ MA } \\
\hline $\mathrm{PC}$ & $-0.722 *$ & 1.000 & -0.352 & $0.947 * *$ & $-0.747 *$ & 1.000 & $0.673 *$ & $0.673 *$ & -0.157 & 1.000 & 0.350 & 0.602 \\
\hline Sig. & 0.028 & - & 0.353 & 0.000 & 0.021 & - & 0.047 & 0.047 & 0.687 & - & 0.355 & 0.087 \\
\hline \multicolumn{13}{|l|}{$\mathrm{CA}$} \\
\hline $\mathrm{PC}$ & $0.691 *$ & -0.352 & 1.000 & -0.481 & $0.874 * *$ & -0.509 & 1.000 & $-0.921 * *$ & 0.534 & 0.350 & 1.000 & -0.504 \\
\hline Sig. & 0.039 & 0.353 & - & 0.227 & 0.002 & 0.162 & - & 0.000 & 0.139 & 0.355 & - & 0.167 \\
\hline \multicolumn{13}{|l|}{$\mathrm{C}$} \\
\hline $\mathrm{PC}$ & $-0.677 *$ & $0.947 * *$ & -0.481 & 1.000 & $-0.895^{* *}$ & $0.673^{*}$ & $-0.921 * *$ & 1.000 & $-0.694^{*}$ & 0.602 & -0.504 & 1.000 \\
\hline Sig. & 0.022 & 0.000 & 0.227 & - & 0.000 & 0.047 & 0.000 & - & 0.012 & 0.087 & 0.167 & - \\
\hline
\end{tabular}

*The correlation is significant at the 0.05 level

**The correlation is significant at the 0.01 level

significant negative correlations with callose accumulation. These findings confirm that malic acid play an important role in ISOP $76 \mathrm{Al}$ tolerance, but the same was not observed in ISOP 239.

\section{Molecular markers detection}

Plants obtained from hydroponic culture were screened using specific molecular markers. The results of molecular screen are summarized in Table 6 and Fig. 5. The products of CAPS marker amplification resulting from enzymatic digestion allow to discriminate between two ALMT1 alleles (Sasaki et al. 2004). Our data indicate that ISOP 76, Maringá and Chinese Spring possess ALMT1-2, while ISOP 239 had ALMT1-1 allele.

The SPF and LPF markers (Fig. 5) allow the identification of the type of promoter present in the gene ALMT1 (Sasaki et al. 2006). In the $\mathrm{F}_{0}$ and $\mathrm{F}_{3}$ generations of ISOP 76, type IV promoter was detected, but it could not be detected in the DH line. ISOP $239 \mathrm{~F}_{0}$ generation showed the presence of type $\mathrm{V}$ promoter while $\mathrm{F}_{3}$ generation had type I promoter. No promoter was detected in the DH line of ISOP 239. As expected, the standard varieties showed the presence of the promoters type VI for Maringá and type I and III for Chinese Spring.

The SSR3 markers signalize repeated sequences in the intron 3 (Raman et al. 2006). The SSR3a marker 
Table 5 Pearson correlations (PC) between screening tests for ISOP 239: root length (RL), malic acid exudation (MA), citric acid exudation (CA) and callose accumulation (C)

\begin{tabular}{|c|c|c|c|c|c|c|c|c|c|c|c|c|}
\hline & \multicolumn{4}{|l|}{$\mathrm{F}_{0}$} & \multicolumn{4}{|l|}{$\mathrm{F}_{3}$} & \multicolumn{4}{|l|}{$\mathrm{DH}$} \\
\hline & RL & MA & $\mathrm{CA}$ & $\mathrm{C}$ & RL & MA & $\mathrm{CA}$ & $\mathrm{C}$ & RL & MA & $\mathrm{CA}$ & $\mathrm{C}$ \\
\hline \multicolumn{13}{|l|}{ RL } \\
\hline $\mathrm{PC}$ & 1.000 & -0.023 & 0.447 & $-0.768 * *$ & 1.000 & -0.631 & 0.497 & $-0.940 * *$ & 1.000 & -0.414 & -0.045 & $-0.896 * *$ \\
\hline Sig. & - & 0.953 & 0.228 & 0.004 & - & 0.068 & 0.173 & 0.000 & - & 0.268 & 0.909 & 0.000 \\
\hline \multicolumn{13}{|l|}{ MA } \\
\hline $\mathrm{PC}$ & -0.023 & 1.000 & 0.027 & 0.057 & -0.631 & 1.000 & -0.340 & 0.403 & -0.414 & 1.000 & 0.331 & 0.070 \\
\hline Sig. & 0.953 & - & 0.946 & 0.884 & 0.068 & - & 0.371 & 0.282 & 0.268 & - & 0.384 & 0.857 \\
\hline \multicolumn{13}{|l|}{ CA } \\
\hline $\mathrm{PC}$ & 0.447 & 0.027 & 1.000 & -0.551 & 0.497 & -0.340 & 1.000 & -0.505 & -0.045 & 0.331 & 1.000 & -0.001 \\
\hline Sig. & 0.228 & 0.946 & - & 0.124 & 0.173 & 0.371 & - & 0.166 & 0.909 & 0.384 & - & 0.998 \\
\hline \multicolumn{13}{|l|}{$\mathrm{C}$} \\
\hline $\mathrm{PC}$ & $-0.728 * *$ & 0.057 & -0.551 & 1.000 & $-0.940 * *$ & 0.403 & -0.505 & 1.000 & $-0.896 * *$ & 0.070 & -0.001 & 1.000 \\
\hline Sig. & 0.004 & 0.884 & 0.124 & - & 0.000 & 0.282 & 0.166 & - & 0.000 & 0.857 & 0.998 & - \\
\hline
\end{tabular}

*The correlation is significant at the 0.05 level

**The correlation is significant at the 0.01 level

Table 6 Summary results of specific ALMT1 molecular markers amplification, consequent promoter type and allele, and expected gene expression (EGE) based on promoter type and observed malic acid exudation (OME)

\begin{tabular}{|c|c|c|c|c|c|c|c|c|c|}
\hline Variety & $\begin{array}{l}\text { CAPS } \\
\text { (bp) }\end{array}$ & Allele $^{a}$ & $\begin{array}{l}\text { SPF } \\
\text { (bp) }\end{array}$ & LPF (bp) & $\begin{array}{l}\text { Promoter } \\
\text { type }^{b}\end{array}$ & $\begin{array}{l}\text { SSR3a } \\
\text { (bp) }\end{array}$ & $\begin{array}{l}\text { SSR3b } \\
\text { (bp) }\end{array}$ & $\mathrm{EGE}^{\mathrm{c}}$ & $\begin{array}{l}\text { OME (mg/ } \\
\mathrm{L})^{\mathrm{d}}\end{array}$ \\
\hline $\begin{array}{l}\text { Chinese } \\
\text { Spring }\end{array}$ & $50 ; 57$ & $\begin{array}{l}\text { ALMT1- } \\
\quad 2\end{array}$ & 612 & $\begin{array}{r}1190 \\
1993\end{array}$ & I and III & 233 & - & $\begin{array}{l}\text { Low/ } \\
\text { medium }\end{array}$ & - \\
\hline Maringá & $50 ; 57$ & $\begin{array}{l}\text { ALMT1- } \\
\quad 2\end{array}$ & - & 1600 & VI & - & - & High & 1.99 \\
\hline $76 \mathrm{~F}_{0}$ & $50 ; 57$ & $\begin{array}{l}\text { ALMT1- } \\
2\end{array}$ & - & 1470 & IV & 233 & - & $\begin{array}{l}\text { Medium/ } \\
\text { high }\end{array}$ & 12.87 \\
\hline $76 \mathrm{~F}_{3}$ & $50 ; 57$ & $\begin{array}{l}\text { ALMT1- } \\
2\end{array}$ & - & 1470 & IV & - & - & $\begin{array}{l}\text { Medium/ } \\
\text { high }\end{array}$ & 27.48 \\
\hline $76 \mathrm{DH}$ & $50 ; 57$ & $\begin{array}{l}\text { ALMT1- } \\
2\end{array}$ & - & - & - & - & - & - & 43.33 \\
\hline $239 \mathrm{~F}_{0}$ & 107 & $\begin{array}{l}\text { ALMT1- } \\
1\end{array}$ & - & 1750 & V & 233 & 173 & High & 3.65 \\
\hline $239 \mathrm{~F}_{3}$ & 107 & $\begin{array}{l}\text { ALMT1- } \\
1\end{array}$ & 612 & 1190 & I & - & 173 & Low & 3.74 \\
\hline 239DH & 107 & $\begin{array}{l}\text { ALMT1- } \\
1\end{array}$ & - & - & - & - & - & - & 7.72 \\
\hline
\end{tabular}

\footnotetext{
${ }^{a}$ Determined with the molecular marker CAPS

b Determined with the molecular markers SPF and LPF. (-) absence of amplification and detection of the markers

c Based on bibliographic data

d These values were obtained for $100 \mu \mathrm{M}$ of $\mathrm{AlCl}_{3}$
} 


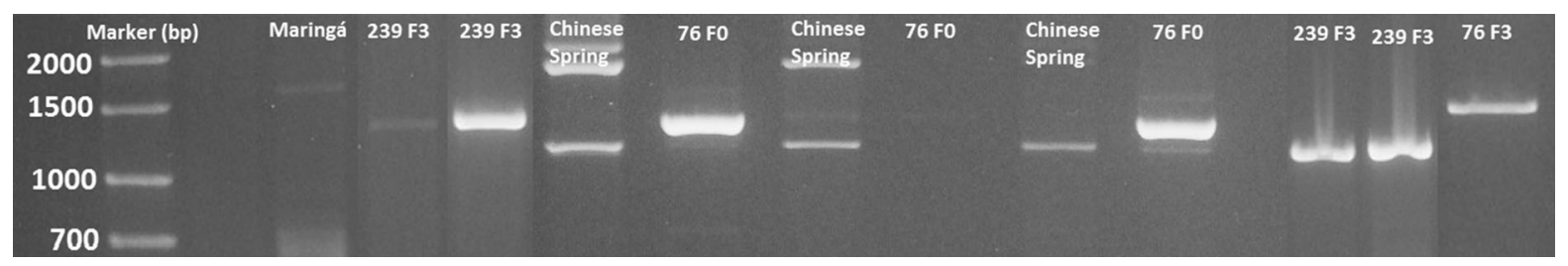

Fig. 5 Detection of LPF marker amplifications products on $1.4 \%(w / v)$ agarose gel

was detected in Chinese Spring and in $\mathrm{F}_{0}$ generations of both wheat landraces. On the other hand, SSR3b marker was only detected in $\mathrm{F}_{0}$ and $\mathrm{F}_{3}$ generations of ISOP 239.

\section{Discussion}

\section{Screening tests of $\mathrm{Al}$ tolerance}

The eriochrome cyanide $\mathrm{R}$ staining is a reliable qualitative method allowing to differentiate between tolerant and susceptible plants within a sample or a population. However, this method does not allow weighting the plant's answer to aluminium among individuals or plants sets in the population. In this study the eriochrome cyanide $\mathrm{R}$ staining was used to assess the level of $\mathrm{Al}$ tolerance of the generations of wheat landraces. According to Ma et al. (2001) the exposure to cationic aluminium affects root development and its elongation, can give an evidence that plant can cope with this metal presence. Overall root elongation (Fig. 2) and elongation ratio data confirm that ISOP 76 have $\mathrm{Al}$ tolerance and its performance is equal or even better than Maringá. However, the root performance of Maringá improved with $\mathrm{Al}$ increasement in the growing medium (Fig. 2). At the same time, ISOP 239 suffers the highest impact of $\mathrm{Al}$ bioavailability in root elongation, confirming that this landrace has an $\mathrm{Al}$ susceptible. In both cases, $\mathrm{F}_{0}$ shown better root elongation in the presence of $100 \mu \mathrm{M} \mathrm{Al}$. The elongation ratio decreased along the series $F_{0}>F_{3}>D H$ lines, which could mean that both landraces are losing their ability to cope with bioavailable aluminum, possibly due to the loss of some genetic variability. Nevertheless, the elongation ratio decrease was less than 10 and $14 \%$ for the ISOP 76 , in the presence of 100 and $200 \mu \mathrm{M} \mathrm{Al}$, respectively, showing that landraces generations kept significant part of its $\mathrm{Al}$ tolerance. The findings about
Maringá combined with the increase of root performance and the low organic acid exudation, possibly mean that aluminium triggers different tolerance mechanisms, for instance the internal Al neutralization, avoiding organic acid exudation.

The accumulation of callose in roots is a typical plant response to stress, including the one caused by aluminium (Zhang et al. 1994). In this case, accumulation of this polysaccharide is an evidence of plant susceptibility. Callose accumulation demonstrated to be greatly correlated with the experimental variants and generations (Table 3), being its amounts higher when $\mathrm{Al}$ increases. Among the landraces, ISOP 239 shown a higher callose deposition, indicating that it is less tolerant to the presence of aluminium. At the same time, the initial population of ISOP 76 produces amounts of callose that resemble Maringá behaviour. The deposition of callose in $\mathrm{F}_{3}$ and DH lines of ISOP 76 increases in the presence of $\mathrm{Al}$, reflecting some difficulties to cope with metal bioavailability.

Overall, the performed screening tests (Table 2) confirmed the Al tolerance of ISOP 76 landrace, which offers some features comparable to Maringá, such as high root length and relative lower callose accumulation. At the same time, ISOP 239 landraces confirm to be susceptible to $\mathrm{Al}$, showing opposite features: more than $55 \%$ of susceptible individuals, lower root elongation ratio and the highest callose deposition.

Quantification of organic acids in exudates

Malate exudation was acknowledged as the main mechanism responsible for wheat tolerance to $\mathrm{Al}(\mathrm{Ma}$ et al. 2001; Ryan et al. 2009). Malic acid was also implicated in the plant responses to different abiotic stresses (Lance and Rustin 1984; Pinheiro de Carvalho et al. 1991). This account also appears to be true for ISOP 76, where malate was actively exuded 
in the presence of $\mathrm{Al}$ (Fig. 4a), as previously documented by Sharma et al. (2016). The malic acid exudation has positive and significantly influenced by experimental conditions (100 and $200 \mu \mathrm{M} \mathrm{Al}$ ) and generations $\left(\mathrm{F}_{0}, \mathrm{~F}_{3}, \mathrm{DH}\right)$ variants (Table 3$)$. Organic acid exudation was also significantly correlated with root length (negative correlation) and callose (positive) for ISOP 76 (Tables 4, 5). Our observation suggests that malate exudation is probably the main mechanism for $\mathrm{Al}$ neutralization resulting in $\mathrm{Al}$ tolerance of ISOP 76. Lack of enhanced malate exudation in Al tolerant Maringá may imply that this cultivar features a different $\mathrm{Al}$ coping mechanism(s).

In contrast, citrate is continuously exuded by wheat under stress-free conditions, which was corroborated by our observations of ISOP 76 and by Ryan et al. (2009). The highest exudation of citric acid by ISOP 76 was reported in $\mathrm{Al}$ free medium, while it dropped in the presence of $\mathrm{Al}$, both in the $\mathrm{F}_{0}$ and $F_{3}$ generations. An increase of citric acid exudation is observed in $\mathrm{F}_{3}$ and $\mathrm{DH}$ line in the presence of $100 \mu \mathrm{M}$ Al. Wang et al. (2006) demonstrated that in the presence of aluminium, citrate exudation in some wheat genotypes may be inhibited. In the case of ISOP 76 this inhibition was not total, occurring citric acid exudation even in the presence of $200 \mu \mathrm{M} \mathrm{Al}$, although a significant switch to malate exudation occurs in the roots. No significant changes in citric acid exudation in response to $\mathrm{Al}$ exposure were detected in Al susceptible ISOP 239. One can hypothesize that through Al-triggered activation of ALMT1 the usually citrate exudation in some plants can be switch to malate exudation resulting in an increase of plant tolerance to the stress. Chelating capacity of citrate is rather higher than malate because of the presence of three instead of two carboxylic groups (Yang et al. 2013). However, we hypothesize that malic acid could be more effective than citric acid in $\mathrm{Al}$ neutralization since its cellular pool is higher and can be supplied by different metabolic pathways, reaching in some tissues up to $10 \mathrm{mM}$ (Lance and Rustin 1984; Pinheiro de Carvalho et al. 1991). At the same time, citric acid supply depends mainly from Krebs cycle and root cellular pool of this acid is always lower (Popova and Pinheiro de Carvalho 1998). There is also the fact that malate exudation is specifically promoted by the presence of the specific TaALMT1 transporter, controlled by the appropriate $A L M T 1$ gene alleles and promoters.

\section{Molecular markers detection}

The data of organic acid exudation point out to the probable presence of TaALMT1 transporter protein coded by $A L M T 1$ gene in ISOP 76 landrace, triggering malic acid exudation, leading to precipitation of cationic aluminium.

Molecular analyses revealed that ISOP 76, Maringá and Chinese Spring share the same ALMT1-2 allele, while ISOP 239 had the ALMT1-1 allele (Table 6). The ALMT1-2 allele can be detected both in tolerant and susceptible plants and its presence depends of geographical origin of wheat (Raman et al. 2008). Initially, this allele was predominantly reported in the susceptible and moderately tolerant plants (Zhou et al. 2007), such as Chinese Spring and Scout 66 (Sasaki et al. 2006). On the other hand, the presence of $A L M T 1-1$ allele was detected in $\mathrm{Al}$ tolerant Atlas 66 (Sasaki et al. 2006). The ALMT1-1 and ALMT1-2 alleles' expression in Scout 66 and Atlas 66 was constitutive and not induced by $\mathrm{Al}$. Tolerance screening tests and measurements of organic acid exudation showed that ISOP 239 was susceptible to $\mathrm{Al}$ and exuded low levels of malic acid despite the presence of $A L M T 1-1$ allele. However, in ISOP 76, owning the ALMT1-2 allele, high levels of malic exudation are in agree with $\mathrm{Al}$ tolerance and citric acid exudation under control conditions.

In the $\mathrm{F}_{0}$ and $\mathrm{F}_{3}$ generations of the tolerant ISOP 76 , the type IV promoter of ALMT1-2 allele that endorses high to moderate expression of the ALMT1 gene was detected. Interestingly, gene promoters were not detected in the DH lines. All ISOP 76 lines appeared to be $\mathrm{Al}$ tolerant in presence of $100 \mu \mathrm{M} \mathrm{Al}$, which agrees with the increase of acid malic exudation (Table 6). These results seem to indicate that allele gene expression do not determine the rates of malic acid exudation, although the promoter type IV is correlated with Al tolerance (Raman et al. 2008) and malic acid exudation. This finding was not supported by the presence of ALMT1-1 type V promoters in ISOP $239 \mathrm{~F}_{0}$, which convey the highest gene expression (Sasaki et al. 2006), but do not result in the increase of malate exudation when roots were exposed to aluminium. This observation also indirectly suggests that $\mathrm{Al}$ tolerance in Maringá is 
achieved not due to the activation of the ALMT1 gene, and the Maringá's mechanism of Al tolerance is not present in ISOP 239 landrace nor it is responsible for $\mathrm{Al}$ tolerance of the ISOP 76 landrace. In addition, $\mathrm{F}_{3}$ of ISOP 239 had the $A L M T 1-1$ type I promoter and the DH line did not exhibit the presence of any promotors. The type I promoter variant transmitted low gene expression, which corresponds to the lowest malate exudation and lack of $\mathrm{Al}$ tolerance. The variation in ISOP 239 ALMT1-1 promoters can be explained by the heterogeneity of initial landrace population and the selection process for the $\mathrm{Al}$ susceptibility.

Our findings concerning the SSR markers obtained for Chinese Spring and Maringá remain in agreement with Raman et al. (2006). Presence of SSR3a in $F_{0}$ of both landraces and absence in $\mathrm{F}_{3}$ and the $\mathrm{DH}$ lines may be explained by the fact that these repeating sequences were lost during the selection process. The presence of SSR3b marker in $\mathrm{F}_{0}$ and $\mathrm{F}_{3}$, but its lack in the DH line of ISOP 239 could indicate that these repeated sequences are specific to ALMT1-1 and vanished during the process of production of the $\mathrm{DH}$ lines from male $F_{1}$ progeny.

Overall, our results seem to indicate that malate exudation and ALTM1-2 gene allele are probably involved in the key tolerance mechanism of ISOP 76 landrace to $\mathrm{Al}$ toxicity. The $\mathrm{Al}$ tolerance of ISOP 76 landraces measured by root elongation slightly decreased along with the selection process $\mathrm{F}_{0}>\mathrm{DH}$ $>\mathrm{F}_{3}(100 \mu \mathrm{M} \mathrm{Al})$ and $\mathrm{F}_{0}>\mathrm{DH}>\mathrm{F}_{3}(200 \mu \mathrm{M} \mathrm{Al})$. This variation of root elongation was almost inverse to the increase of malate exudation, that occurs along the series $\mathrm{F}_{0}<\mathrm{F}_{3}<\mathrm{DH}(100 \mu \mathrm{M} \mathrm{Al})$ and $\mathrm{F}_{3}<\mathrm{DH}$ $<\mathrm{F}_{0}(200 \mu \mathrm{M} \mathrm{Al})$. The variation in malate exudation in the roots of ISOP 76 could be explained by the detected polymorphism of the ALMT1, using molecular markers (Table 6). These results seems to point out that malate exudation is an important mechanism that plants activate to neutralize metal and mitigate its toxic action in roots. This fact explains the observed negative correlation with root elongation and positive correlation with callose accumulation. These observations also point out to the polygenic nature of $\mathrm{Al}$ tolerance and support our previous findings, reporting high variability and heterogeneity of $\mathrm{Al}$ tolerance among the Madeiran wheat landraces (Pinheiro de Carvalho et al. 2003, Ganança et al. 2007). It implies a high coexistence probability of different tolerance mechanism (Kochian et al. 2005; Sharma et al. 2016) that could be differentially engaged depending on the level of Al bioavailability. One can hypothesize that promoter type IV of ALMT1 is heritably transmitted by the female progenitor, which explain its disappearance from the DH lines, while these lines still maintained ability to exude malate. It might also explain the observation that the response to aluminium of some lines is lower in the presence of $200 \mu \mathrm{M} \mathrm{Al}$ than in $100 \mu \mathrm{M} \mathrm{Al}$.

\section{Conclusions}

In conclusion, both ISOP 76 and ISOP 239 showed typical tolerance and susceptibility to $\mathrm{Al}$ stress responses, respectively. ISOP 76 demonstrated a superior Al tolerance that appears to be in part related with malic acid exudation. Malic acid exudation depends on the presence of ALMT1 gene that was detected in both landraces. However, only ISOP 76 exude malic acid in significant quantities. This difference between ISOP 76 and ISOP 239 can be related with the presence of different genes alleles, ALMT1-2 and ALMT1-1, respectively, and thus exhibited different effectiveness in the landraces' response to the Al stress. However, different gene alleles and promoter types could only partially explain dissimilarities observed among the original landraces, their advanced generations and the $\mathrm{DH}$ lines, in response to $\mathrm{Al}$ toxicity.

Acknowledgements The authors are grateful to the Madeiran farmers providing samples of wheat landraces, and to all staff of CGR ISOPlexis Gene bank and of the Department of Biological Sciences of Alberta University for support and access to laboratory facilities. This work got the funding support from the programs INTERREG III-B, contract 05/MAC/4.1/C15 and Madeira PO 14-20, contract CASBio, ref $^{\mathrm{a}}$. M1420-01-0145-FEDER-000011.

\section{Compliance with ethical standards}

Conflict of interest The authors declare that they have no conflict of interest.

Human and animal rights No human participants or animals were involved in this research.

Informed consent This manuscript is original and submitted with the consent of all authors. 


\section{References}

Aniol A (1990) Genetics of tolerance to aluminium in wheat (Triticum aestivum L. Thell). Plant Soil 123:223-227

Basu U, Godbold D, Taylor GJ (1994) Aluminium resistance in Triticum aestivum associated with enhanced exudation of malate. J Plant Physiol 144:747-753

Chao S, Somers D (2015) Wheat and barley DNA extraction in 96-well plates. MAS wheat. http://maswheat.ucdavis.edu/ protocols/general_protocols/DNA_extraction_003.htm. Accessed 23 July 2015

dos Santos TMM, Slaski JJ, Pinheiro de Carvalho MAA, Taylor GJ, Clemente Vieira MR (2005) Evaluating the Madeiran wheat germplasm for aluminium resistance using aluminium-induced callose formation in root apices as a marker. Acta Physiol Plant 27:297-302

dos Santos TMM, Ganança F, Slaski JJ, Pinheiro de Carvalho MÂA (2009) Morphological characterization of wheat genetic resources from the Island of Madeira, Portugal. Genet Resour Crop Evol 56:363-375

dos Santos TMM, Nóbrega H, Ganança JFT, Silva E, Afonso D, Gutiérres AFM, Slaski JJ, Khadem M, Pinheiro de Carvalho MAA (2012) Genetic variability of high molecular weight glutenin subunits in bread wheat from continental Portugal, Madeira and Canary Islands. Genet Resour Crop Evol 59:1377-1388

Ganança JFT, Abreu I, Sousa NF, Paz RF, Caldeira P, dos Santos TMM, Costa G, Slaski JJ, Pinheiro de Carvalho MÂA (2007) Soil conditions and evolution of aluminium resistance among cultivated and wild plant species on the Island of Madeira. Plant Soil Environ 6:239-246

Haug A (1984) Molecular aspects of aluminium toxicity. CRC Crit. Ver. Plant Sci. 1:345-373

Jones N, Ougham H, Thomas H, Pašakinskienë I (2009) Markers and mapping revisited: finding your gene. New Phytol 183:935-966

Kochian LV, Pineros MA, Hoekenga OA (2005) The physiology, genetics and molecular biology of plant aluminium resistance and toxicity. Plant Soil 274:175-195

Lance C, Rustin P (1984) The central role of malate in plant metabolism. Physiol Vég 22:625-641

Ma JF, Ryan PR, Delhaize E (2001) Aluminium tolerance in plants and the complexing role of organic acids. Trends Plant Sci 6:1360-1385

Ma H, Bai G, Lu W (2006) Quantitative trait loci for Aluminium resistance in wheat cultivar Chinese Spring. Plant Soil 283:239-249

Madeira M, Furtado A, Jeanroy E, Herbillon AJ (1994) Andisols of Madeira Island (Portugal). Characteristics and classification. Geoderma 62:363-383

Megazyme International Ireland (2012) L-Malic Acid Assay Procedure. Ireland.https://secure.megazyme.com/L-MalicAcid-Assay-Kit. Accessed 21 July 2015

Megazyme International Ireland (2014) Citric Acid Assay Procedure. Ireland.https://secure.megazyme.com/CitricAcid-Assay-Kit. Accessed 21 July 2015

Murashige T, Skoog F (1962) A revised medium for rapid growth and bio assays with tobacco tissue cultures. Physiol Plant 15:473-497
Pinheiro de Carvalho MÂA, Zemlyanukhin AA, Eprintsev AT (1991) The malate dehydrogenase system from higher plants. Structure, proprieties, functions and regulation in plant cell. Voronezh University Press, Voronezh

Pinheiro de Carvalho MÂA, Slaski JJ, dos Santos TMM, Ganança FT, Abreu I, Taylor GJ, Clemente Vieira MR, Popova T, Franco E (2003) Identification of aluminium resistant genotypes among Madeiran regional wheats. Commun Soil Sci Plant Anal 34:2973-2985

Popova TN, Pinheiro de Carvalho MÂA (1998) Citrate and isocitrate in plant metabolism. Biochim Biophys Acta Bioenerg 1364(3):307-325

Raman H, Raman R, Wood R, Martin P (2006) Repetitive indel markers within the ALMT1 gene conditioning aluminium tolerance in wheat (Triticum aestivum L.). Mol Breed 18:171-183

Raman H, Ryan PR, Raman R, Stodart BJ, Zhang K, Martin P, Wood R, Sasaki T, Yamamoto Y, Mackay M, Hebb DM, Delhaize E (2008) Analysis of TaALMT1 traces the transmission of aluminium resistance in cultivated common wheat (Triticum aestivum L.). Theor Appl Genet $16: 343-354$

Rout GR, Samantaray S, Das P (2001) Aluminium toxicity in plants: a review. Agronomie 21:3-21

Ryan PR, Raman H, Gupta S, Horst WJ, Delhaize E (2009) A second mechanism for aluminium resistance in wheat relies on the constitutive efflux of citrate from roots. Plant Physiol 149:340-351

Ryan PR, Tyerman SD, Sasaki T, Furuichi T, Yamamoto Y, Zhang WH, Delhaize E (2011) The identification of aluminium-resistance genes provides opportunities for enhancing crop production on acid soils. J Exp Bot 62:920

Sasaki T, Yamamoto Y, Ezaki B, Katsuhara M, Ahn SJ, Ryan PR, Delhaize E, Matsumoto H (2004) A wheat gene encoding an aluminium-activated malate transporter. Plant J 37:645-653

Sasaki T, Ryan PR, Delhaize E, Hebb DM, Ogihara Y, Kawaura K, Noda K, Kojima T, Toyoda A, Matsumoto H, Yamamoto Y (2006) Sequence upstream of the wheat (Triticum aestivum L.) ALMT1 gene and its relationship to aluminium resistance. Plant Cell Physiol 47:1343-1354

Sharma T, Dreyer I, Kochian L, Piñeros MA (2016) The ALMT family of organic acid transporters in plants and their involvement in detoxification and nutrient security. Front Plant Sci 7(1488):1-12

Shewry PR (2009) Wheat J Exp 60:1537-1553

Vieira A (1988) A Madeira na Rota dos Descobrimento e a Expansão Atlântica. Separata da Revista da Universidade de Coimbra XXXIV: 571-580

Wang P, Bi S, Wang S, Ding Q (2006) Variation of wheat root exudates under aluminium stress. J Agric Food Chem 54:10040-10046

Yang Y, Ji C, Ma W, Wang S, Wang S, Han W, Mohammat A, Robinson D, Smith P (2012) Significant soil acidification across northern China's grasslands during 1980s-2000s. Glob Chang Biol 18:2292-2300

Yang L-T, Qi Y-P-, Jiang H-X, Chen L-S (2013) Roles of organic acid anion secretion in aluminium tolerance of higher plants. BioMed Res Int 173682:1-16. https://doi. org/10.1155/2013/173682 
Zhang G, Hoddinitt J, Taylor GJ (1994) Characterization of 1,3- $\beta$-D-Glucan (Callose) synthesis in roots of Triticum aestivum in response to aluminium toxicity. $\mathrm{J}$ Plant Physiol 144:229-234

Zhou L, Bai G, Carver B (2007) Identification of new sources of aluminium resistance in wheat. Plant Soil 297:105-118

\section{Publisher's Note}

Springer Nature remains neutral with regard to jurisdictional claims in published maps and institutional affiliations. 